\title{
Ovine gammaherpesvirus 2 infections in cattle without typical manifestations of sheep-associated malignant catarrhal fever and concomitantly infected with bovine coronavirus
}

\author{
Selwyn Arlington Headley ${ }^{1,2,3}$ - Gisele Augusta Amorim de Lemos ${ }^{1} \cdot$ Alais Maria Dall Agnol ${ }^{3,4}$. \\ Ana Aparecida Correa Xavier ${ }^{1}$. Victória Coronado Antunes Depes ${ }^{5}$. Carolina Yuka Yasumitsu ${ }^{4}$. \\ Thalita Ernani Silva Oliveira ${ }^{1}$. Luara Evangelista Silva ${ }^{1}$ - Tatiane Cargnin Faccin ${ }^{1}$. Amauri Alcindo Alfieri ${ }^{3,4,6}$. \\ Júlio Augusto Naylor Lisboa ${ }^{3,5}$
}

Received: 24 July 2021 / Accepted: 3 November 2021 / Published online: 15 November 2021

(c) Sociedade Brasileira de Microbiologia 2021

\begin{abstract}
Sheep-associated malignant catarrhal fever (SA-MCF) is a severe, frequently fatal, lymphoproliferative disease that affects a wide variety of ruminants and is caused by ovine gammaherpesvirus 2 (OvHV-2), a member of the MCF virus (MCFV) complex. The typical clinical manifestations of SA-MCF are well known and easily recognized by veterinarians, resulting in clinical diagnosis of MCF when characteristic clinical signs are present. This article describes the findings observed in cattle infected with OvHV-2 but without typical clinical manifestations of SA-MCF. Three calves with episodes of diarrhea before death and a yearling that died suddenly were investigated. Gross alterations were not suggestive of SA-MCF. Histopathology revealed a combination of proliferating vascular lesions (PVLs) and necrotizing vasculitis in three animals (two calves and the yearling); with PVLs being identified only at the carotid rete mirabile of two calves infected with OvHV-2. Additional significant histopathologic lesions included atrophic enteritis, portal lymphocytic hepatitis, interstitial pneumonia, suppurative bacterial bronchopneumonia, and pulmonary hemorrhage. An immunohistochemical assay designed to identify only antigens of MCFV revealed, positive, intralesional, intracytoplasmic immunoreactivity within epithelial cells of multiple tissues of all animals with PVLs. PCR assays amplified OvHV-2 DNA from multiple tissues of the animals that contained MCFV proteins, confirming the MCFV identified as OvHV-2. Additionally, bovine coronavirus (BCoV) nucleic acids were amplified from tissues of all animals, including the animal not infected by OvHV-2. Collectively, these findings confirmed the participation of OvHV-2 in the development of the disease patterns observed in these animals that were concomitantly infected by $\mathrm{BCoV}$ and provide additional confirmation that cattle can be subclinically infected with OvHV-2. Consequently, the real occurrence of OvHV-2-related disease may be more elevated than reported, since asymptomatic or subclinically infected animals are not likely to be investigated for OvHV-2. Furthermore, PVLs should be included as possible histologic indicators of OvHV-2-related diseases in ruminants.
\end{abstract}

Keywords Asymptomatic infections · Atrophic enteritis $\cdot \mathrm{BCoV} \cdot$ Malignant catarrhal fever virus $\cdot$ OvHV-2; Proliferating vascular lesions $\cdot$ Subclinical SA-MCF

\section{Introduction}

Responsible Editor: Fernando R. Spilki

Selwyn Arlington Headley

selwyn.headley@uel.br

Extended author information available on the last page of the article
Malignant catarrhal fever (MCF) is a lymphoproliferative disease, caused by the MCF virus (MCFV) complex, that affects a wide variety of mammalian hosts in different geographical locations [1-3]. Moreover, all MCFV members are genetically and antigenically related $[4,5]$ since they share the 15A antigenic epitope and have marked similarity at the conserved regions of the DNA polymerase gene $[4,6]$. Although all members of the MCFV complex are 
located within the subfamily Gammaherpesvirinae, genus Macavirus [5, 7], not all members of this genus have been associated with MCF. Furthermore, all members of MCFV complex known to cause MCF [1-3] have not been fully recognized by the International Committee on Taxonomy of Viruses [7]. Nevertheless, most studies have been focused on aspects associated with the agents of epidemiological importance of $\mathrm{MCF}$, namely ovine gammaherpesvirus 2 (OvHV-2) and alcelaphine gammaherpesvirus 1 (AlHV-1). OvHV-2 produces sheep associated-MCF (SA-MCF) which is endemic in ruminants worldwide [2, 3, 8], while AlHV-1 is the cause of wildebeest-associated MCF that occurs in cattle from Africa and in ruminants maintained in zoological parks $[3,8]$.

The clinical manifestations associated with SA-MCF are easily recognized by practicing veterinarians $[1,3]$, so a clinical diagnosis of SA-MCF is readily achieved when typical signs are present in affected animals. The clinical syndromes of SA-MCF in ruminants include the classical head and eye form $[1,9,10]$, in addition to the alimentary [9], chronic $[11,12]$, neurological $[13,14]$, peracute, and cutaneous [1, 2] manifestations of MCF. Moreover, abrupt fever $\left(>41^{\circ} \mathrm{C}\right)$ is characteristic of MCF [1], even in the alimentary form in which severe diarrhea may be present [9]. Additionally, cattle with neurological manifestations [13, 15], and healthy cows [13,15] and the American bison, Bison bison [16-18] developed typical SA-MCF histologic lesions but without clinical signs suggestive of MCF. Furthermore, intralesional antigens of MCFV were identified in cattle with bovine respiratory disease, BRD [19], pulmonary [20], and renal diseases [21], but without any clinical manifestation and/ or diagnosis of MCF, suggesting that these animals were infected by OvHV-2 but without the characteristic clinical signs of SA-MCF.

This then raises the question as to the possibility that asymptomatic or subclinical infection in cattle by OvHV-2 being more frequent than previously considered. Therefore, the real incidence of SA-MCF may be more elevated than documented [3]. Accordingly, this paper is opportune as it presents the pathological, immunohistochemical, and molecular findings of cattle infected with OvHV-2 but without typical clinical manifestation of SA-MCF, providing additional evidence of this unusual manifestation of MCF.

\section{Materials and methods}

\section{Geographical locations, animals, and clinical information}

Animals from two distinct geographical locations were used during this study. The first consisted of a dairy breeding unit (farm A) located on the outskirts of the city of Toledo, approximately, $305 \mathrm{~km}$ distant from Londrina, Paraná, Southern Brazil. The other location was a beef cattle farm located at Altamira do Parana (farm B), situated approximately $227 \mathrm{~km}$ distant from Londrina, being $107 \mathrm{~km}$ away from farm A. Additionally, cattle at these farms were not reared or had any contact with sheep.

Three Holstein calves, from farm A, with a clinical history of posterior paresis that progressed to permanent recumbency were attended at the Large Animal Clinics, Veterinary Teaching Hospital, Universidade Estadual de Londrina (VTH-UEL), Paraná, Southern Brazil. The consulting veterinarian indicated that the clinical manifestations initiated after the animals were 3-11 days of age and that three other calves developed similar clinical signs and died. $\mathrm{He}$ further indicated that intestinal fragments of these animals were submitted for histopathologic evaluation; serum collected ante-mortem and fragments of the brain were sent for the identification of Neospora caninum by ELISA and PCR. One of the samples contained $N$. caninum DNA; enteritis suggestive of infection by Cryptosporidium spp. was diagnosed in all calves by histopathology. Cows at this dairy unit are routinely immunized against leptospirosis, clostridial diseases, bovine coronavirus ( $\mathrm{BCoV})$, and bovine viral diarrhea virus (BVDV). Additionally, all calves were medicated at the dairy unit with penicillin ( $G$ procaine and $G$ benzathine) and flunixin meglumine. Furthermore, cerebrospinal fluid (CSF) and blood samples were collected for laboratory evaluations. However, one calf died spontaneously, and two were euthanized, within 1 day after hospitalization.

Tissue sections of a 1.5-year-old Nelore heifer from farm $\mathrm{B}$, with a clinical diagnosis of clostridiosis, were received for pathologic diagnosis at the Laboratory of Animal Pathology, VTH-UEL. Farm B is a small beef cattle unit that recently introduced animals from other locations. The referring veterinarian indicated that an additional 11 animals were maintained within the same area as the yearling. Furthermore, three heifers died suddenly after presenting episodes of fetid diarrhea; one of these had emphysematous swelling at the larger leg muscles which induced a clinical diagnosis of clostridial disease. The death of all animals was acute and sudden, i.e., being found dead without any observable clinical manifestations. He also indicated that cattle at this farm were fed with star grass (Cynodon nlemfuensis), had poor conversion rates, while water was ad libitum.

\section{Post-mortem evaluation and tissue collection}

All calves from farm A were submitted for routine post-mortem evaluations soon after death. Tissue samples of all major organs of the calves (lungs, liver, kidney, intestine, brain, spinal cord, and spleen) were collected, fixed by immersion in $10 \%$ buffered formalin solution, routinely processed for histopathologic evaluation, and visualized with the 
hematoxylin and eosin (H\&E) stain. Similar tissue fragments of the yearling from farm $\mathrm{B}$, but without the central nervous system, were received and processed as indicated. Additionally, selected formalin fixed paraffin-embeded (FFPE) sections of the carotid rete mirabile (CRM) of the calves from farm A were stained with the Verhoeff-Van Gieson (VVG) histochemical method to identify elastin.

Furthermore, selected FFPE tissues sections of the lungs, intestine, and kidneys of all animals were used in immunohistochemical (IHC) assays to identify intralesional antigens of viruses. Moreover, tissue fragments of selected organs were maintained frozen or in $70 \%$ alcohol solution until used in molecular investigations.

\section{Immunohistochemical identification of viral disease pathogens}

Selected FFPE tissues sections of the lungs, kidneys, and small intestine of all animals were used in IHC assays designed to identify intralesional antigens of bovine respiratory syncytial virus, (BRSV), bovine alphaherpesvirus 1 (BoHV-1), BVDV [22], and MCFV [15]. Furthermore, FFPE tissue fragments of the brain were used to identify intralesional antigens of MCFV and BoHV-5. Positive controls consisted of FFPE tissue sections known to contain antigens of BRSV, BVDV, BoHV-1 [22], BoHV-5 [23], and OvHV-2 [15]. Two negative controls were used in all IHC assays: the first consisted of replacing the primary antibodies by its respective diluent, while in the second, the primary antibodies were administered on FFPE tissues known to demonstrate negative immunoreactive to the primary antibodies. Negative and positive controls were included in all IHC assays.

\section{Molecular detection of infectious disease pathogens}

The nucleic acid extraction was performed from $500-\mu \mathrm{l}$ proteinase K pre-treated aliquots of tissue suspensions (brain, lung, kidney, spleen, intestine, and liver; Supplemental Table 1) using a combination of the phenol/chloroform/ isoamyl alcohol and silica/guanidine isothiocyanate methods $[24,25]$. The extracted nucleic acids were eluted in $50 \mu \mathrm{l}$ of UltraPure $^{\mathrm{TM}}$ DEPC-treated water (Invitrogen ${ }^{\mathrm{TM}}$ Life Technologies, Carlsbad, CA, USA) and stored at $-80^{\circ} \mathrm{C}$. Sterile, ultrapure water was used as the negative control in all nucleic acid extractions and subsequent procedures.

Molecular assays were performed to detect the nucleic acids of the principal infectious disease agents (Supplemental Table 1) associated with respiratory and systemic diseases of cattle. These included OvHV-2 [26], BVDV [27], BRSV [28], BoHV-1 and -5 [29], BCoV [30], bovine parainfluenza virus 3 [31], Mannheimia haemolytica [32], Pasteurella multocida [33], Histophilus somni [34], and
Mycoplasma bovis [35]. Positive controls consisted of the utilization of nucleic acids of these infectious agents derived from previous studies: OvHV-2 [36], BVDV, BoHV-1, BRSV, BCoV, BRSV, M. haemolytica, P. multocida, H. somni, M. bovis [37, 38], and BoHV-5 [23]. As indicate above, negative control consisted of sterile, ultrapure water; positive and negative controls were included in each molecular assay.

\section{Nucleotide sequence analysis of OvHV-2 and BCoV}

The products of OvHV-2 tegument protein gene (amplified from the liver; animal \#4) and the $\mathrm{N}$ gene of $\mathrm{BCoV}$ (from fragments of the kidney; animal \#2) were purified using the PureLink ${ }^{\circledR}$ Quick Gel Extraction and PCR Purification Combo Kit (Invitrogen ${ }^{\circledR}$ Life Technologies, Carlsbad, CA, USA), quantified by using a Qubit ${ }^{\circledR}$ Fluorometer (Invitrogen ${ }^{\circledR}$ Life Technologies, Eugene, OR, USA), and submitted to sequencing in both directions with the forward and reverse primers used in the respective molecular assays in an ABI3500 Genetic Analyzer sequencer with the BigDye Terminator v3.1 Cycle Sequencing Kit (Applied Biosystems ${ }^{\circledR}$, Foster City, CA, USA).

Sequence quality analyses and consensus sequences were obtained using PHRED and CAP3 software (http:// asparagin.cenargen.embrapa.br/phph/), respectively. Similarity searches were performed with nucleotide (nt) sequences deposited in GenBank using the Basic Local Alignment Search Tool software (https://blast.ncbi.nlm. nih.gov/Blast.cgi). The identity of the nt sequences was confirmed by comparison with reference sequences available in GenBank. Sequence alignment and identity matrix were performed by using the BioEdit software version $7.2 .5[39]$.

\section{Phylogenetic analyses of OvHV-2 and BCoV}

Multiple and pairwise alignments were done for the nt sequences of OvHV-2 and BCoV derived from this study with strains available in GenBank, including prototype strains for each organism, using MEGA software version 7.0.26 [40]; sequence identity matrices were then constructed with the BioEdit software version 7.2.5 [39]. Phylogenetic trees were obtained by using the maximum likelihood method with the Jukes-Cantor model for OvHV-2 [41] and with the general time reversible model for BCoV [42] using MEGA software version 7.0.26 [40]. Murine herpes virus served as the outgroup for the OvHV-2 phylogenetic analysis, while human coronavirus was used as the outgroup for the $\mathrm{BCoV}$ analysis. Bootstrapping probabilities were calculated using 1000 replicates. 


\section{Results}

\section{Clinical manifestations and laboratory evaluations}

All Holstein calves were afebrile, with body temperatures varying between 36.1 and $37.9^{\circ} \mathrm{C}$; fever was not observed in the Nelore yearling. The clinical manifestations observed in all animals are summarized in Table 1; duration of disease was chronic in the Holstein calves and hyperacute with sudden death in the yearling. Additionally, all Holstein calves had a combination of enteric and neurological disease manifestations; fetid diarrhea was observed in all of these, but no definite neurological syndrome was established. Furthermore, alterations were not observed in all CSF and blood samples submitted for laboratory analyses.

\section{Gross, histopathologic, and histochemical findings}

The principal gross lesions are summarized in Table 2; all Holstein calves had hypertrophy of mesenteric and illiac lymph nodes with a mixture of pulmonary and intestinal alterations. Hemorrhagic enteritis (Fig. 1A) was observed only in animal \#1, ulcerative abomasitis (Fig. 1B) in animals \#2 and \#3, and with pulmonary diseases (Fig. 1C-D) in animals \#2, \#3, and \#4. Gross alterations were not observed in the lungs of animal \#1 (Fig. 1E).

Histopathologic alterations were predominantly enteric, pulmonary, and vascular in animals \#2-4 (Table 2); except in the intestinal fragments received from the Nelore yearling (\#4), where severe postmortem autolysis was observed, probably due to inadequate fixation. Atrophic hemorrhagic enteritis with cryptal necrosis (Fig. 2A) was observed only in animal \#1; alternatively, there was severe atrophic enteritis with cryptal necrosis (Fig. 2B-C) and ulcerative abomasitis (Fig. 2D) in animals \#2 and \#3. Pulmonary lesions were more severe in animal \#3; being consisted predominantly of severe, multifocal to coalescing suppurative bacterial bronchopneumonia and thrombosis (Fig. 2E-F) with islands of interstitial pneumonia and necrotizing bronchitis. Although pulmonary hemorrhage was predominant in animal \#4, there were foci of interstitial pneumonia with necrotizing vasculitis (Fig. 2G). Furthermore, there was a mixture of interstitial pneumonia and bronchopneumonia in animal \#2, while the pulmonary findings in animal \#1 were non-specific, consisting predominantly of edema and congestion. Additionally, significant histopathologic alterations included portal lymphocytic hepatitis (animals \#2-4; Fig. 2H) and lymphocytic interstitial nephritis (animals \#2 and \#4).

Furthermore, proliferating vascular lesions (PVLs), interpreted as hyperplastic arteriopathy, were observed in multiple tissues of animals \#2-4 (Fig. 3A-C) and at the CRM of animals \#2 and 3 (Fig. 3B-C) but not in calf \#1; lymphocytic vasculitis was observed only at the CRM of animal \#2 (Fig. 3D-E). Moreover, histochemical evaluation with the VVG stain revealed severe proliferation of collagenous tissue that resulted in partial obliteration of arteries at the CRM of animals \#2 and \#3 (Fig. 3F-G) but not in animal \#1 (Fig. 3H).

\section{Immunohistochemical identification of disease pathogens}

Positive, widespread, intracytoplasmic immunoreactivity to MCFV antigens were observed in multiple tissues of animals \#2-4 (Table 2), with immunolabeling being predominantly pulmonary, renal, and intestinal. Antigens of MCFV were not identified in any tissues of animal \#1 (Supplemental Fig. 1A-C). Positive immunoreactivity to MCFV antigens was identified within the epithelial cells of peribronchial glands and bronchial epithelium of the lungs (animals \#2-4, Fig. 4A-C), epithelial cells of renal tubules (animals \#2-4, Fig. 4D), and within cryptal epithelial cells of the small intestine (animals \#2-3; Fig. 4E). Furthermore, intralesional MCFV antigens were identified within epithelial cells of bronchi and bronchiole that contained suppurative exudate in animal \#3 with bacterial
Table 1 Clinical manifestations and the outcome of cattle concomitantly infected by OvHV-2 and BCoV

\begin{tabular}{|c|c|c|c|c|}
\hline Animals & Biological data & Clinical manifestations & Duration (days) & Outcome \\
\hline \multicolumn{5}{|l|}{ Farm A } \\
\hline$\# 1$ & Holstein, female, 32 days old & $\begin{array}{l}\text { Fetid yellow diarrhea } \\
\text { Flaccid tetraparesis } \\
\text { Permanent recumbency }\end{array}$ & 22 & Euthanasia \\
\hline$\# 2$ & Holstein, female, 34 days old & $\begin{array}{l}\text { Fetid yellow diarrhea } \\
\text { Flaccid tetraparesis } \\
\text { Permanent recumbency }\end{array}$ & 31 & Euthanasia \\
\hline \#3 & Holstein, female, 37 days old & $\begin{array}{l}\text { Fetid yellow diarrhea } \\
\text { Flaccid tetraparesis } \\
\text { Permanent recumbency }\end{array}$ & 25 & Spontaneous death \\
\hline \multicolumn{5}{|l|}{ Farm B } \\
\hline \#4 & Nelore, female, 18 months old & Sudden death & 1 & Spontaneous death \\
\hline
\end{tabular}


Table 2 Principal gross and histopathologic findings with immunohistochemical and molecular investigations of disease agents in cattle with SA-MCF

\begin{tabular}{|c|c|c|c|c|c|c|}
\hline \multirow[t]{2}{*}{ Animals } & \multirow[t]{2}{*}{ Principal gross lesions } & \multirow[t]{2}{*}{ Histopathologic lesions } & \multirow{2}{*}{$\begin{array}{l}\text { MCFV } \\
\text { immunore- } \\
\text { activity }\end{array}$} & \multicolumn{2}{|c|}{$\begin{array}{l}\text { Molecular } \\
\text { identification }{ }^{1}\end{array}$} & \multirow[t]{2}{*}{ Type of infection } \\
\hline & & & & OvHV-2 & $\mathrm{BCoV}$ & \\
\hline$\# 1$ & $\begin{array}{l}\text { Enlarged mesenteric and illiac lymph } \\
\text { nodes } \\
\text { Hemorrhagic enteritis with promi- } \\
\text { nence of Payer patches } \\
\text { Renal congestion }\end{array}$ & $\begin{array}{l}\text { Atrophic hemorrhagic enteritis with } \\
\text { cryptal necrosis } \\
\text { Cerebrum, nonsuppurative encephalitis } \\
\text { with neuronal necrosis } \\
\text { Kidneys, interstitial and vascular } \\
\text { congestion } \\
\text { Lymph nodes, medullary congestion }\end{array}$ & Absent & Absent & $\begin{array}{l}\text { Kidney } \\
\text { Lung } \\
\text { Spleen } \\
\text { Intestine }\end{array}$ & Single \\
\hline$\# 2$ & $\begin{array}{l}\text { Cranioventral pulmonary consolidation } \\
\text { Intestinal congestion with prominence } \\
\text { of Payer patches } \\
\text { Enlarged mesenteric and illiac lymph } \\
\text { nodes } \\
\text { Renal infarction } \\
\text { Ulcerative abomasitis }\end{array}$ & $\begin{array}{l}\text { Atrophic enteritis with cryptal necrosis } \\
\text { Bronchopneumonia } \\
\text { Carotid rete mirabile, intimal prolifera- } \\
\text { tion, and lymphocytic vasculitis } \\
\text { Cerebrum, neuronal necrosis, severe } \\
\text { multifocal gliosis, satellitosis } \\
\text { Interstitial pneumonia } \\
\text { Lymph nodes, follicular lymphoid } \\
\text { hyperplasia } \\
\text { Lymphoplasmacytic interstitial } \\
\text { nephritis } \\
\text { Portal lymphoplasmacytic hepatitis } \\
\text { Renal cortical infarction } \\
\text { Spinal cord, neuronal necrosis } \\
\text { Ulcerative abomasitis }\end{array}$ & $\begin{array}{l}\text { Intestine } \\
\text { Kidneys } \\
\text { Lung }\end{array}$ & $\begin{array}{l}\text { Lung } \\
\text { Kidney }\end{array}$ & $\begin{array}{l}\text { Lung } \\
\text { Kidney }\end{array}$ & Dual \\
\hline \#3 & $\begin{array}{l}\text { Enlarged mesenteric and illiac lymph } \\
\text { nodes } \\
\text { Necrohemorrhagic bronchopneumonia } \\
\text { Ulcerative and perforated abomasitis }\end{array}$ & $\begin{array}{l}\text { Atrophic enteritis with cryptal necrosis } \\
\text { Ballooning degeneration of the tran- } \\
\text { sitional epithelium of the urinary } \\
\text { bladder } \\
\text { Cerebrum and cerebellum, neuronal } \\
\text { necrosis } \\
\text { Depletion of splenic lymphoid tissue } \\
\text { Carotid rete mirabile, intimal prolifera- } \\
\text { tion } \\
\text { Necrotizing bacterial abomasitis } \\
\text { Portal lymphoplasmacytic hepatitis } \\
\text { Proliferative vascular lesions: spleen, } \\
\text { liver, lung } \\
\text { Suppurative bacterial bronchopneu- } \\
\text { monia }\end{array}$ & $\begin{array}{l}\text { Intestine } \\
\text { Kidney } \\
\text { Lung }\end{array}$ & $\begin{array}{l}\text { Brain } \\
\text { Lung }\end{array}$ & $\begin{array}{l}\text { Kidney } \\
\text { Lung } \\
\text { Spleen }\end{array}$ & Dual \\
\hline \#4 & Pulmonary hemorrhage & $\begin{array}{l}\text { Interstitial nephritis with lymphocytic } \\
\text { necrotizing vasculitis } \\
\text { Interstitial pneumonia with lympho- } \\
\text { cytic necrotizing vasculitis } \\
\text { Lymphoplasmacytic myocarditis with } \\
\text { lymphocytic necrotizing vasculitis } \\
\text { Portal lymphocytic hepatitis } \\
\text { Proliferative vascular lesions: kidney, } \\
\text { lung, small intestine } \\
\text { Pulmonary hemorrhage }\end{array}$ & $\begin{array}{l}\text { Kidney } \\
\text { Liver } \\
\text { Lung }^{2}\end{array}$ & $\begin{array}{l}\text { Liver } \\
\text { Lung }\end{array}$ & Lung & Triple \\
\hline
\end{tabular}

Footnote: ${ }^{1}$ Only positive molecular results are shown; ${ }^{2}$ positive immunoreactivity to bovine viral diarrhea virus antigens

pneumonia (Fig. 4F). Additionally, there was positive immunolabeling of MCFV antigens even within epithelial cells of intestinal crypts that contained necrotic debris (Fig. 4G-H), within epithelial cells of the abomasum with necrotizing abomasitis (Fig. 4I), renal capillaries (Fig. 4J), and within hepatocytes and epithelial cells of bile ducts of animal \#4 with portal lymphocytic hepatitis (Fig. 4K-L). Moreover, there was positive, patchy, localized, intracytoplasmic immunoreactivity to BVDV antigens within bronchial epithelial cells of the lungs of animal \#4 (Supplemental Fig. 1D). Positive immunoreactivity was not identified for antigens of BRSV, BoHV-1, and BoHV-5. 
Fig. 1 Gross observations in calves simultaneously infected with ovine gammaherpesvirus 2 and bovine coronavirus. The intestinal mucosa is bloody with prominence of Payer patch (A) and there is multifocal necrohemorrhagic abomasitis (B). Comparative lung analysis of Holstein calves: observe areas of pulmonary consolidation $(\mathbf{C}$, animal \#2), severe necrohemorrhagic bronchopneumonia at the cranioventral region of the lungs (D, animal \#3), and the normal gross features ( $\mathbf{E}$, animal \#1). Ruler, scale in centimeters

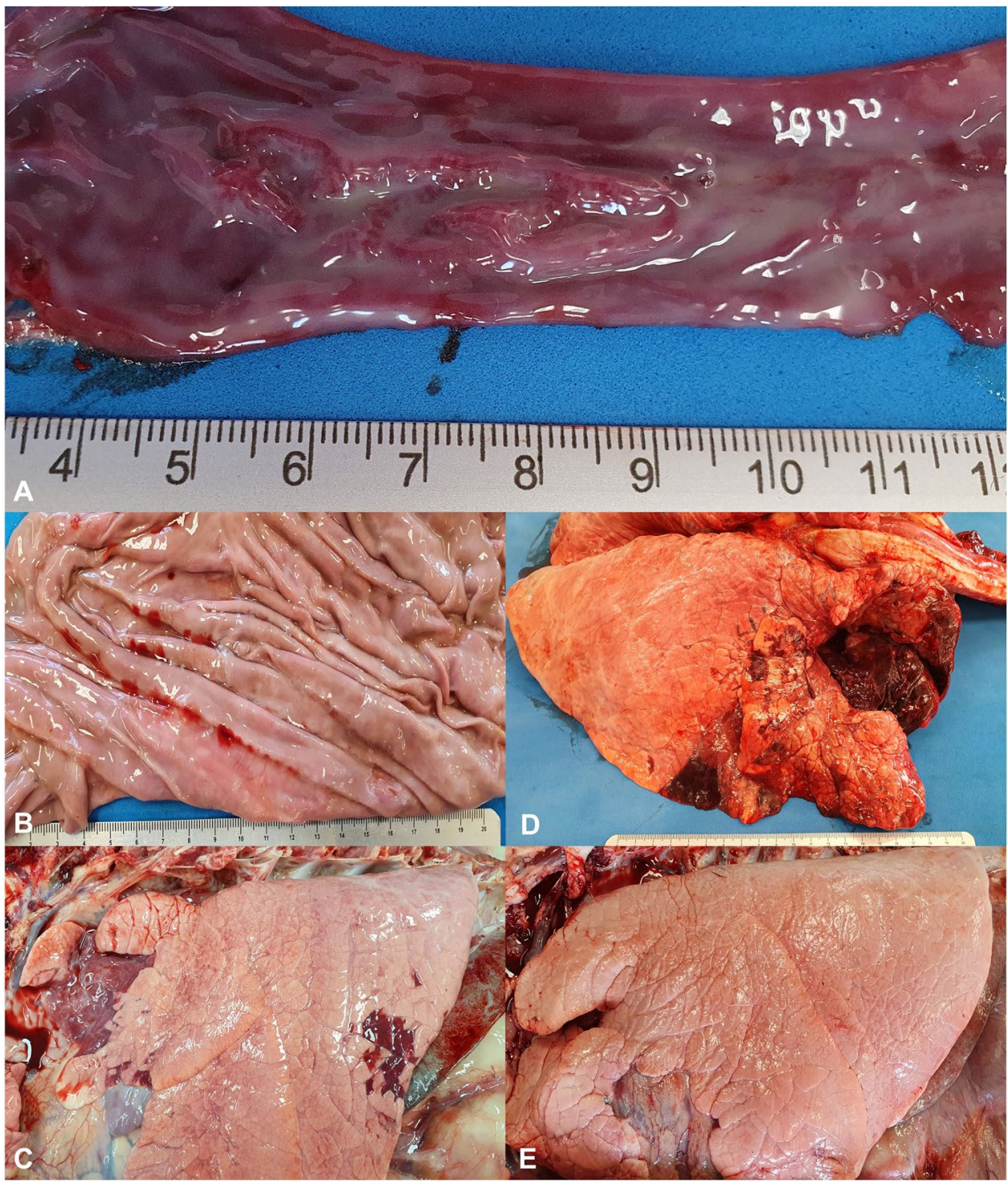

\section{Molecular identification of infectious disease pathogens}

Nucleic acids of BCoV and OvHV-2 were amplified from multiple tissues of all animals, except in animal \#1 from which OvHV-2 DNA was not amplified (Table 2). Sequence analyses confirmed the specificity of the amplicons of the OvHV-2 tegument protein gene derived from the liver of animal \#4 and the $\mathrm{BCoV} \mathrm{N}$ gene originated from the kidney of animal \#2. These nt sequences are deposited in GenBank (OvHV-2, MZ500969; BCoV, MZ500968). Furthermore, nucleic acids of the other infectious disease pathogens evaluated were not amplified from any of the tissues submitted from the four calves (Supplemental Table 1).

\section{Phylogenetic analyses of the partial nucleotide sequences of OvHV-2 and BCoV}

The strain from this study clustered with the prototype strains of OvHV-2 (Fig. 5). The wild-type OvHV-2 strain derived from this study showed nt sequence identities ranging from 97.9 to $100 \%$ with other 19 OvHV-2 strains deposited in GenBank. Moreover, this strain demonstrated $100 \%$ and $98.6 \%$ sequence identity with the prototype strains BJ1035 and NC007646 of OvHV-2, respectively, and 98.6\% nt sequence identity with strains (GenBank accession numbers \# JQ780444, MZ221210, and KJ658293) previously reported from Brazil.

Comparative analysis between the nucleotide sequence of the $\mathrm{N}$ gene of the $\mathrm{BCoV}$ strain identified in this study with 
Fig. 2 Histopathologic findings observed in calves concomitantly infected by ovine gammaherpesvirus 2 and bovine coronavirus. There is severe atrophic enteritis (A) and accumulation of necrotic debris (arrows) within intestinal crypts (B); closer view of cryptal necrosis (C). Observe ulcerative abomasitis (D) and suppurative bronchopneumonia associated with foci (arrows) of intralesional bacterial colonies (E); closer view of intralesional bacteria $(\mathbf{F})$. There is interstitial pneumonia with necrotizing vasculitis (arrow; G) and portal lymphocytic hepatitis (H). Hematoxylin and eosin stain. Bar: A, D $500 \mu \mathrm{m} ; \mathbf{B}, \mathbf{G}$ $100 \mu \mathrm{m} ; \mathbf{C} 20 \mu \mathrm{m} ; \mathbf{E} 200 \mu \mathrm{m} ; \mathbf{F}$, H $50 \mu \mathrm{m}$

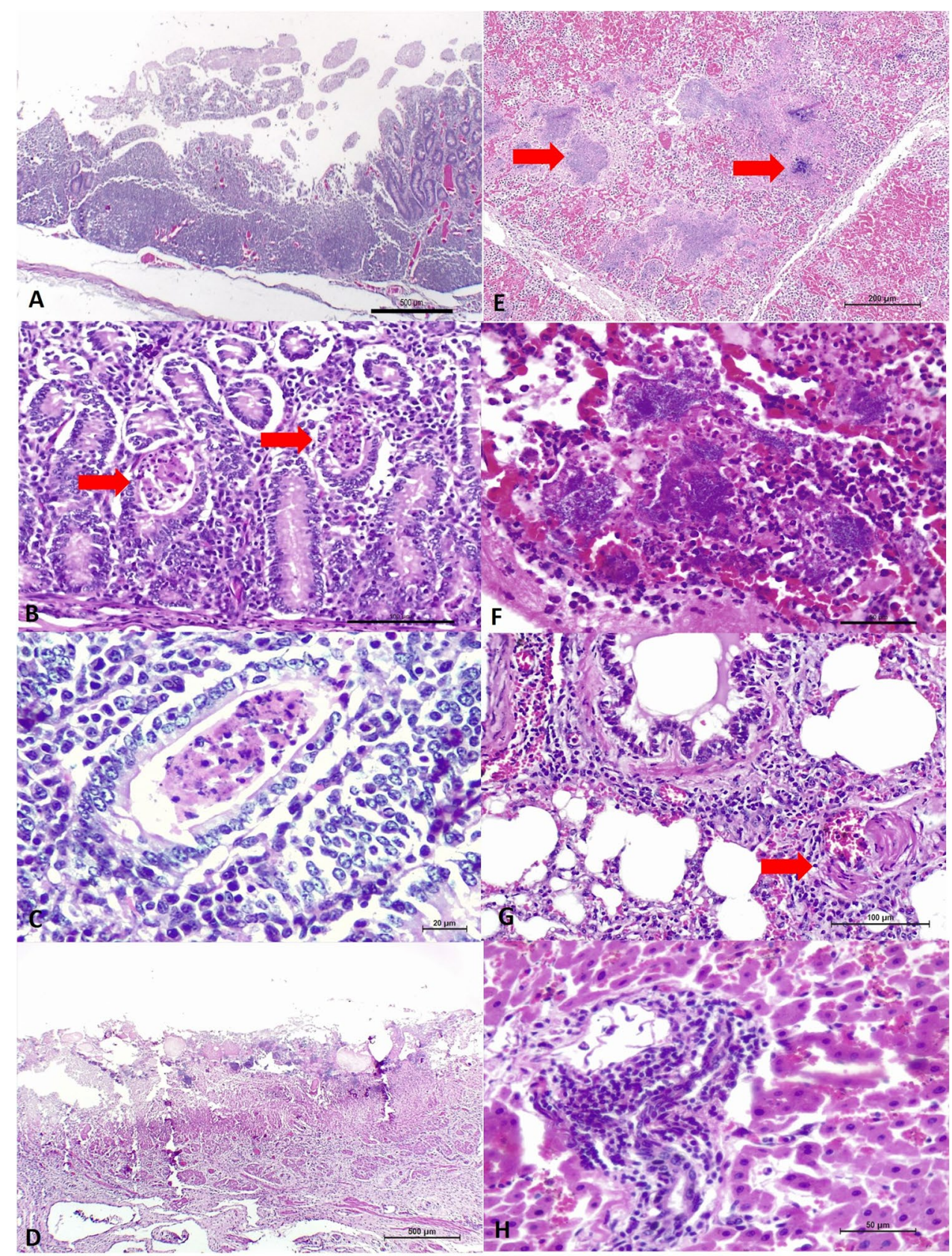

other $34 \mathrm{BCoV}$ strains available in GenBank revealed nt identities ranging from 98.3 to $100 \%$. The Mebus prototype strain (GenBank accession number \# U00735) and other strains previously reported from Brazil (GenBank accession numbers \# KM982442, KP860296, and KU167034) showed 99.5\% sequence nt identity with the BCoV strain identified in this study.

\section{Discussion}

The results of the histopathologic, histochemical, immunohistochemical, and molecular investigations confirmed that these animals without any typical clinical manifestation or gross lesions suggestive of SA-MCF were infected by OvHV-2. More specifically, the histopathologic 
Fig. 3 Proliferative arterial lesions associated with infection by ovine gammaherpesvirus 2 in animals. There is proliferation of the intimal layer of arteries from the lung $(\mathbf{A})$ and at the carotid rete mirabile (B, C); observe degeneration of the intimal layer (arrows, B) and luminal obliteration (C). There is transmural lymphocytic vasculitis at the carotid rete mirabile of calf \#2 (D), that is better appreciated at the closer view (E). Observe intimal proliferation at the carotid rete mirabile of calves infected by OvHV-2 $(\# 2, \mathbf{F}$; \#3, G) with partial obliteration of an affected artery of animal \#3 (G). Compare the absence of intimal proliferation at the carotid rete mirabile in calf \#1 that was not infected by OvHV-2 (H). Hematoxylin and eosin stain (A-E); VerhoeffVan Gieson histochemical method (F-H). Bars: A $50 \mu \mathrm{m}$; B $20 \mu \mathrm{m}$; C, E-H $100 \mu \mathrm{m}$; D $200 \mu \mathrm{m}$

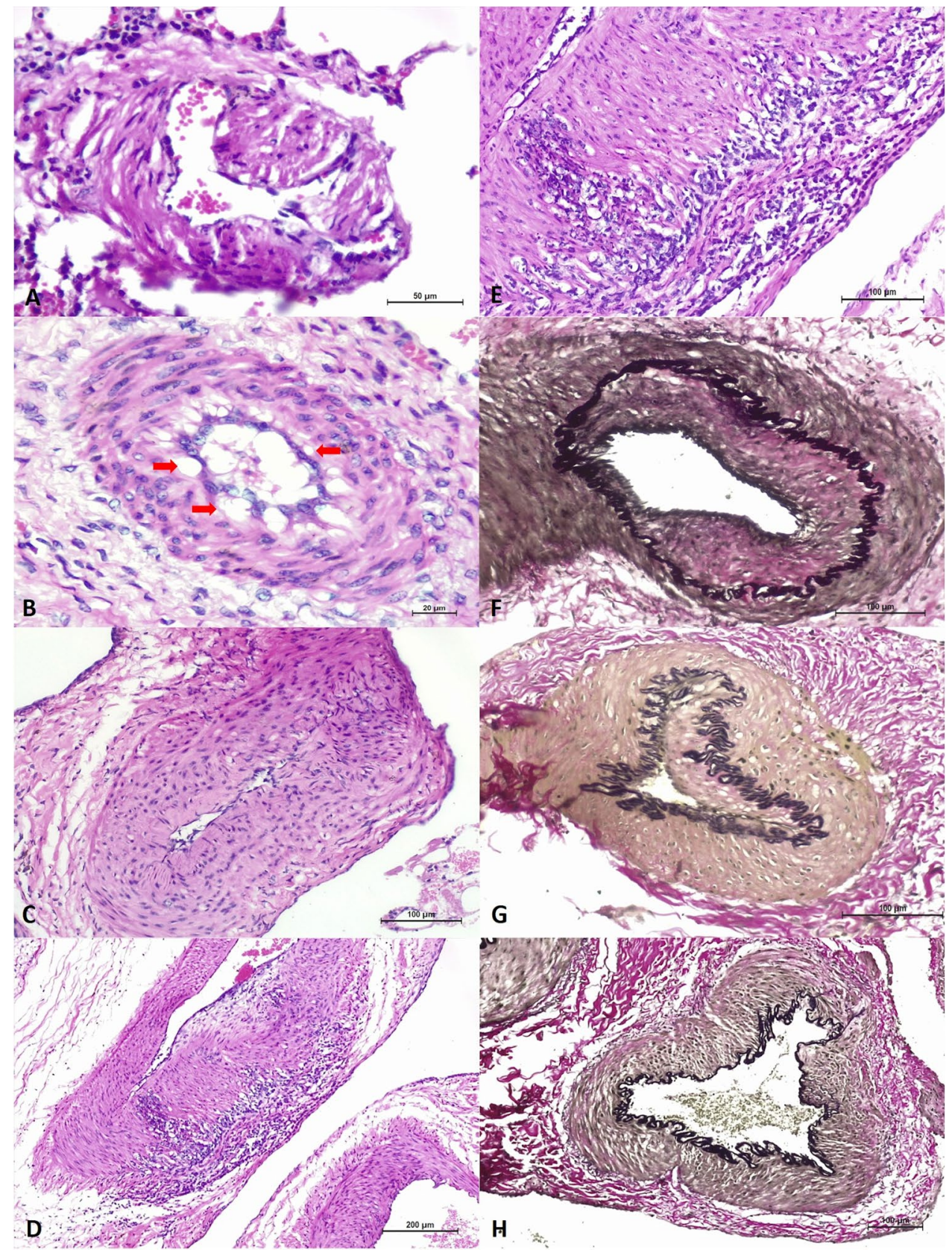

identification of widespread PVLs in several tissues and the histochemical demonstrating of intimal thickening at the CRM in two calves are suggestive of chronic manifestations of SA-MCF; similar typical cases of chronic SA-MCF were previously described in cattle $[11,12]$ and bison [43]. Moreover, IHC identified intralesional MCFV antigens in multiple tissues of two calves and the yearling, while the PCR assays confirmed these viral proteins as nucleic acids of OvHV-2; similar results were described in cattle [15] and in a sheep [44] spontaneously infected by OvHV-2. Finally, the concomitant amplification of $\mathrm{BCoV}$ nucleic acids from multiple tissues of all animals indicates that this virus participated in the development of the diseases herein described, while the IHC identification of intralesional BVDV antigens from the lung of animal \#3 demonstrated that this calf was also infected by this virus. Consequently, singular (animal \#1), dual (animals \#2 and 3), and triple infections were confirmed (animal \#4).

The clinical manifestations demonstrated by all animals from this study were nonspecific for any neurological syndrome and were not suggestive of SA-MCF [1, 9, 10]; consequently, a clinical diagnosis of MCF was not made. Moreover, fever which is part of the alimentary form (Constable et al. 2017), and characteristic of SA-MCF (O'Toole 
Fig. 4 Immunohistochemical identification of malignant catarrhal fever virus antigens in cattle. There is positive intracytoplasmic immunoreactivity to MCFV antigens within bronchial epithelial cells (A), (B)), and epithelium (arrow) of peribronchial glands $(\mathbf{C})$ ) of the lungs. Observe intracytoplasmic immunolabelling of MCFV antigens within renal tubular epithelium (D)), cryptal epithelial cells (E)), and bronchial epithelium containing purulent exudate $(\mathrm{Ex})(\mathbf{F})$ ). Compare positive immunoreactivity to MCFV antigens within epithelial cells of intestinal crypts with (arrow) (G)) and without accumulation of tissue debris $(\mathbf{H})$ ). There is positive immunoreactivity within epithelial cells of the abomasum (I)), renal capillary $(\mathbf{J})$ ), hepatocytes (K)), and bile duct epithelium (L)). Immunoperoxidase counterstained with hematoxylin.

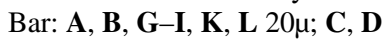
$20 \mu \mathrm{m} ; \mathbf{E}$ and $5,50 \mu \mathrm{m}$

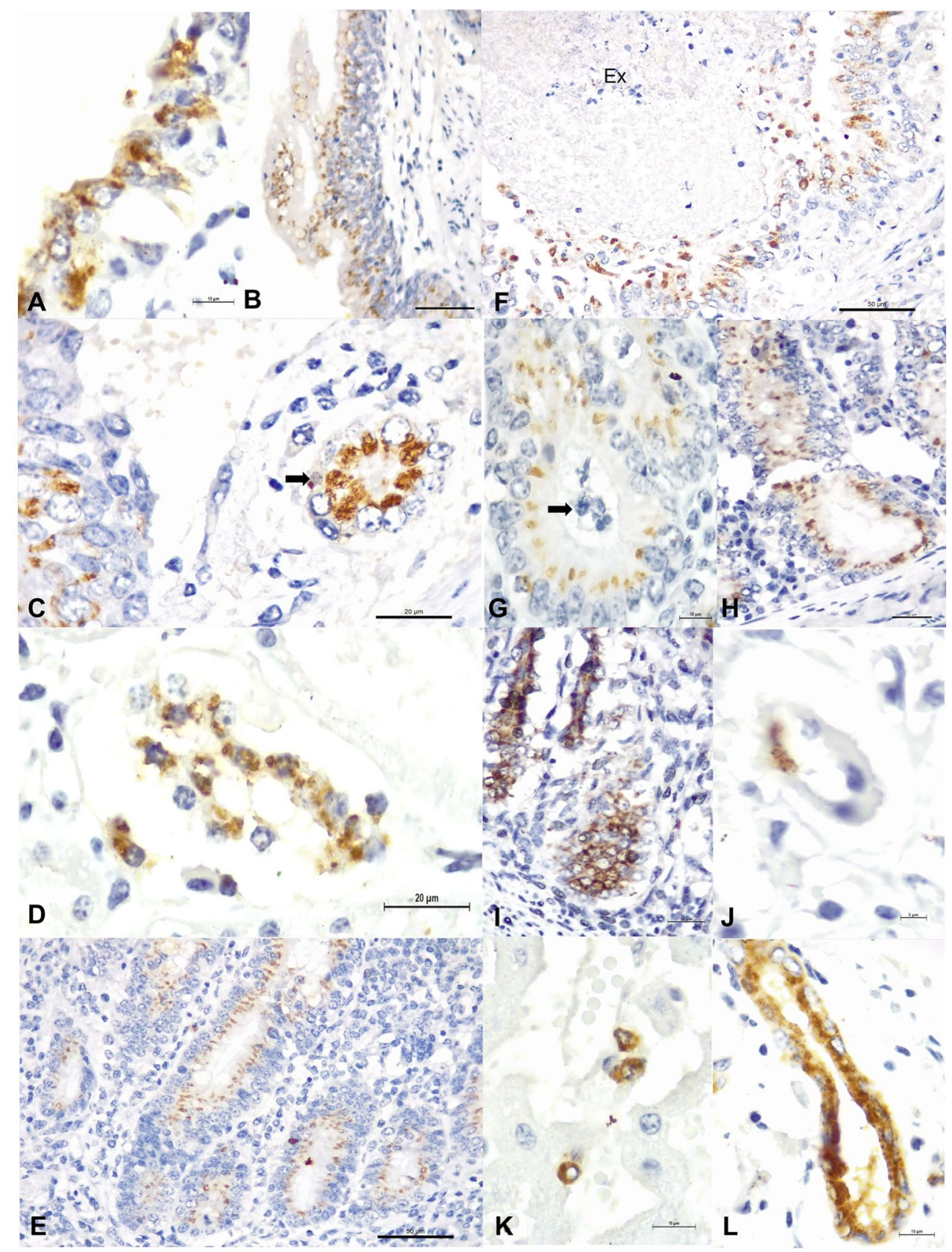

et al. 2014), was not observed in any of the animals from the current study. In fact, MCF was only suspected after histopathological arterial lesions (vasculitis and PVLs) suggestive of SA-MCF were observed in multiple tissues of these animals, with subsequent confirmation by IHC and PCR. Alternatively, cattle without any clinical manifestations, gross, and histologic demonstration of SA-MCF vasculitis contained OvHV-2 DNA [45]. Furthermore, our group has demonstrated the participation of OvHV-2 in cattle with neurological syndromes but without typical clinical manifestations of SA-MCF [15], with similar findings in cattle with pulmonary [19, 20, 22] and renal [21] diseases. Additionally, several reports have confirmed the participation of OvHV-2 in cattle $[13,16,45,46]$ and the American bison [16-18] without typical clinical manifestations of SA-MCF. Moreover, it was suggested that infected animals without typical SA-MCA may be subclinically infected by OvHV-2 [16].

Although the exact reason for the occurrence of subclinical or asymptomatic SA-MCF in ruminants is currently unknown, subclinical infections of OvHV-2 have been associated with stress-related conditions in bison [18], and reduced viral load, non-propagation of free virus or reinfection in cattle [45]. In this case, the viral load was not evaluated, but all animals were concomitantly infected by $\mathrm{BCoV}$, and demonstrated pathologic findings that can be attributed to this viral disease pathogen [47, 48]. Accordingly, 
Fig. 5 Molecular phylogenetic analysis of partial tegument protein gene of ovine gammaherpesvirus- 2 strains by maximum likelihood method based on the Jukes-Cantor model. The analysis involved 19 nucleotide sequences of OvHV-2; murine herpesvirus sequence was used as the out-group. The sequence derived from this study is highlighted ( ). The GenBank reference number, name, country, and species origin of the strains used in this analysis are provided

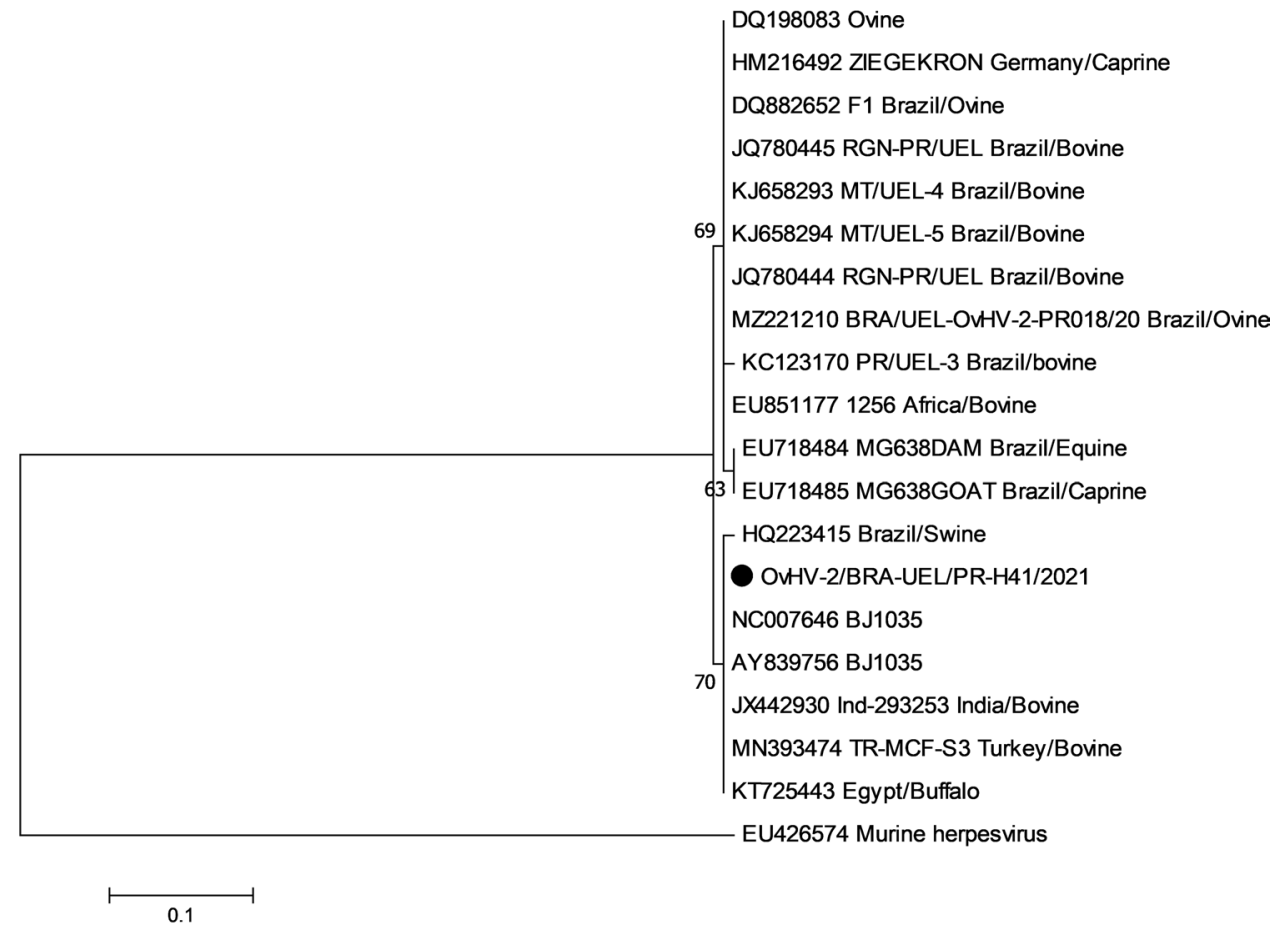

concomitant pulmonary and enteric infections due to $\mathrm{BCoV}$ could have predisposed these animals to infection [48, 49], resulting in asymptomatic or subclinical SA-MCF. Therefore, it seems that under specific conditions, cattle may be asymptomatic or be subclinically infected with OvHV-2, with the possibility of having gross and/or histopathologic lesions characteristic of SA-MCF, but without typical clinical manifestations of this disease; similar asymptomatic manifestations with histopathologic demonstration of disease were described in calves experimentally infected with BoHV-5 [50]. Therefore, subclinical infections or asymptomatic disease status may be a pattern for herpesviruses of cattle. Collectively, these findings confirm the affirmation that SA-MCF or OvHV-2-associated diseases may be underreported worldwide [3], since animals that are asymptomatic would not be investigated for the possible participation of OvHV-2.

$\mathrm{BCoV}$ is a common pneumotropic viral disease pathogen that is associated with respiratory and enteric diseases of cattle worldwide, due to dual tropism for the respiratory and intestinal tracts $[48,51,52]$. Diseases syndromes attributed to the participation of $\mathrm{BCoV}$ in specific age groups of cattle include bovine respiratory disease (BRD), calf pneumonia $[48,53]$, neonatal diarrhea, and winter dysentery [49, 53, 54]. All calves from this study had some form of pulmonary disease demonstrated by histopathology and contained nucleic acids of $\mathrm{BCoV}$ in the lungs, indicating that these animals were infected by $\mathrm{BCoV}[48,54]$. Alternatively, all Holstein calves demonstrated severe enteric disease clinically with histopathologic lesions consistent with those attributed to $\mathrm{BCoV}[47,49,52]$. Although nucleic acids of $\mathrm{BCoV}$ were only amplified from the intestinal fragments of the calf with hemorrhagic enteritis, all calves contained viral BCoV RNA in multiple tissues, so intestinal dissemination could have been associated with viremia [48, 52]. Nevertheless, an interesting finding in this study was the positive immunoreactivity to MCFV antigens within epithelial cells of intestinal crypts, even those that contained necrotic debris, of animals \#2 and 3; similar results were described in cows [15, 20] and a sheep [44]. Additionally, cryptal necrosis as observed in calves \#1-3 are histopathologic manifestations seen in infections due to BCoV [47, $48]$ and BVDV $[55,56]$. However, BVDV nucleic acids or proteins were not identified from the lungs or intestine of these calves, suggesting that this viral disease pathogen did not participate in the development of the diseases patterns herein described and that these animals were concomitantly infected by $\mathrm{BCoV}$ and OvHV-2. Consequently, the role of OvHV-2 in the development of enteric diseases in cattle, either acting as an innocent bystander or a primary contributor [19], must be fully investigated, considering that enteric disease is also associated with MCF in bison [17, 43, 57].

During this study, the PVLs (hyperplastic arteriopathy) were only identified at the CRM of the two calves infected with OvHV-2, being absent in the calf that did not contain MCFV viral proteins or OvHV-2 nucleic acids. These are compelling evidence that PVLs are associated with OvHV-2 infections and are indictive of chronic manifestations of infections due to OvHV-2; similar lesions were described in cattle [11, 12, 15], bison [43], and sheep [44] infected with 
OvHV-2. Moreover, the PVLS herein described in these two calves with resulting partial luminal obliteration with minimum vasculitis can be classified as grade 3 arterial lesions associated with OvHV-2 [17]. The clinical evolution of disease manifestations in these animals varied between 25 and 31 days; comparatively, arterial lesions were more severe in cattle that recovered from MCF after at least 90 days [11, 12] and in bison after 80 days of disease progression [43]. Alternatively, PVLs of less intensity and severity occurred in cattle with acute neurological manifestations [15] and in sheep after 28 days of progressive emaciation [44], suggesting that the degree and extent of PVLs in SA-MCF are time dependent. The marked difference between the cases herein presented and those described in cattle [11, 12] and bison [43] was the absence of typical clinical manifestations of SA-MCF in these calves as well as the cows with neurological manifestations [15]. Although the duration of disease progression was unknown in a retrospective study of BRD, PVLs were significant histologic features to diagnose MCFV-associated pneumonia in cattle with BRD, during which MCFV antigens were identified in 53.3\% (64/120) of all cattle with BRD [19]. Furthermore, since PVLs are considered as the consequence of severe vasculitis [12] that is characteristic of SA-MCF [1], these vascular lesions may be essential histologic elements for the histopathologic diagnosis of OvHV-2-associated diseases in the absence of necrotizing vasculitis. Nonetheless, it is recommended that these histologic vascular alterations must be associated with additional diagnostic strategy (e.g., PCR, IHC, and/or in situ hybridisation) for the efficient confirmation of OvHV2-related diseases.

All animals infected with OvHV-2 had distinct patterns of pulmonary diseases, including interstitial pneumonia (animals \#2 and \#4) and suppurative bronchopneumonia (animal \#4); similar findings were identified in cattle with BRD due to infections with a MCFV, more likely, OvHV-2 [19]. Additionally, necrotizing vasculitis, the hallmark for a histologic diagnosis of MCF [1-3], was only observed in animal \#4; suggesting that this histologic alteration should not be the only histopathologic feature used to arrive at a diagnosis of OvHV-2-associated pneumonia. As indicated previously, PVLs, as identified in the lungs of animals \#3 and \#4, are significant histologic features for the histologic diagnosis of pneumonia associated with MCFV [19]. Furthermore, the pulmonary findings observed in these animals support the theory that OvHV-2 can act as a disease pathogen in the development of pulmonary disease in cattle [2, 19]. Therefore, a histologic diagnosis of OvHV-2-associated pneumonia should not be based exclusively on the finding of necrotizing vasculitis, since OvHV-2 antigens and/or proteins can be identified in tissues of cattle without the characteristic lesion of SA-MCF. Intriguingly in these cases, was the absence of molecular amplification of common bacterial pathogens associated with the development of suppurative bronchopneumonia of cattle from the pulmonary fragments of animal \#3. This inconsistency can be attributed to the submission of pulmonary fragments without bacteria for molecular testing, considering that the lesions in this animal were predominantly cranioventral.

The histopathologic findings observed in the brains of the two calves infected with OvHV-2 are nonspecific for SAMCF, since typical manifestations of necrotizing vasculitis and non-suppurative encephalitis, as described in neurologic MCF [13, 14], were not observed. However, it was demonstrated that the neuropathologic manifestations of SA-MCF seem variable, where typical histologic alterations may be absent in cases of neurological MCF, and require molecular testing to confirm infection, since in situ identification of intralesional viral proteins of OvHV-2 may be inconsistent [58]. Similar inconsistent or lack of in situ labeling of OvHV-2 viral proteins was observed the brains of cattle [15, 59], with patchy IHC demonstration of MCFV antigens in a sheep with histopathologic evidence of SA-MCF [44]. Additionally, positive immunolabeling was not observed in the neurological tissues of the two calves herein described with nonspecific neuropathological alterations, while in one of these (\#3) OvHV-2 nucleic acids were amplified. Accordingly, an efficient diagnosis of OvHV-2-associated encephalitis in cattle would require molecular testing in the absence of typical histologic demonstration of SA-MCF. Nevertheless, additional evaluations of brain tissues of animals using a combination of in situ identification of intralesional OvHV-2 proteins and the molecular amplification of nucleic acids are needed to fully understand the dynamics of OvHV-2 encephalitis in cattle.

All cattle infected with OvHV-2 during this investigation were not maintained on farms that had sheep or were not reared concomitantly with sheep. In most outbreaks of SAMCF in cattle, there is a history of the concomitant rearing of sheep and cattle on the same farm or close to a feedlot and/or farm [1,2], resulting in direct or indirect contact with secretions from the reservoir host [1]. Nevertheless, there are similar documented outbreaks of SA-MCF in cattle [16, 60, 61], white-tailed deer (Odocoileus virginianus) [62], and bison $[17,63]$ in which there is no known history of direct contact between sheep and the infected ruminants. Since all infected cattle from this study did not demonstrate typical clinical manifestations of SA-MCF, the possibility of recrudescence of persistent infection by OvHV-2 [16, 17] cannot be totally discarded. Nonetheless, these findings are indicative of subclinical manifestation of SA-MCF, as was postulated for cattle and bison [16]. Additionally, it was demonstrated that bison reared in properties that are within less than $1 \mathrm{~km}$ distant from locations containing sheep are more likely to develop MCF [63]. Furthermore, the mortality rate associated with SA-MCF seems directly proportional 
to the distance between farms containing lambs and bison feedlots [64]. Consequently, there is no need to have direct comingling between sheep and cattle for the development of SA-MCF or infections due to OvHV-2, since environmental conditions and mechanical vectors may play an important role in the dissemination of this virus over long distances [64].

In conclusion, OvHV-2-associated infections are described in cattle without typical clinical manifestations of SA-MCF but concomitantly infected with BCoV. OvHV-2 infections were confirmed due to disseminated vascular lesions associated with positive immunoreactivity to MCFV antigens in multiple tissues and the amplification of OvHV-2 nucleic acids from these animals. These findings indicate that under special conditions, cattle may be subclinically infected by OvHV-2. Consequently, the occurrence of OvHV-2 infections may be more elevated than previously reported, since ruminants that die without typical clinical manifestations of SA-MCF are not likely to be investigated for the possible participation of OvHV-2. Furthermore, necrotizing vasculitis that is typical of OvHV-2 infections should not be used as the only histologic feature for a histopathologic diagnosis of SA-MCF, since antigens and/or nucleic acids of OvHV-2 can be identified in tissues of cattle without this fundamental histologic diagnostic feature of MCF.

Supplementary Information The online version contains supplementary material available at https://doi.org/10.1007/s42770-021-00653-6.

Acknowledgements Part of this study was possible due to an international agreement between DMVP/UEL/Brazil and ARS/USDA (58-2090-8-068-F). Headley, S.A.; Alfieri, A.A; and Lisboa, J.A.N. are recipients of the National Council of Scientific and Technological Development (CNPq; Brazil) fellowships. Xavier, A.A.C. and Silva, L.E. are recipients of graduate fellowships from the Coordination for the Improvement of Higher Education Personnel (CAPES; Brazil). T.E.S Oliveira is the recipient of a graduate fellowship from the National Council of Scientific and Technological Development (CNPq; Brazil).

Author contribution Headley, S.A. contributed substantially to the conception and design of the study, drafted the initial manuscript, and contributed to the analysis and interpretation of all pathological and immunohistochemical data. Headley, S.A.; Lemos, G.A.A.; and Faccin, T.C. participated in the realization of the post-mortem evaluations. Headley, S.A.; Lemos, G.A.A.; Oliveira, T.E.S; and Faccin, T.C. contributed towards the histopathologic evaluations. Dall Agnol, A.M. and Yasumitsu, C.K. contributed towards the realization of all molecular assays. Dall Agnol, A.M.; Carolina Yuka Yasumitsu, C.K.; and Alfieri, A.A. contributed towards the analysis of all molecular data. Xavier, A.A.C. and Silva, L.E. participated in the realization of all histochemical and immunohistochemical stains and analyses. Depes, V.C.A. and Lisboa, J.A.N. contributed towards the realization of all clinical and laboratorial analyses and interpretations. All authors have read, critically analyzed, approved the final draft of this manuscript, and have agreed to be accountable for all aspects of the study in ensuring that questions related to the accuracy or integrity of any part of the work are appropriately investigated and resolved.

\section{Declarations}

Ethics approval All applicable international, national, and/or institutional guidelines for the care and use of animals were followed. Moreover, the utilization of animals in this study was authorized by the Ethics Committee for the Utilization of Animals, Universidade Estadual de Londrina (CEUA/UEL; protocol \# 835.2019.45).

Conflict of interest The authors declare no competing interests.

\section{References}

1. O'Toole D, Li H (2014) The pathology of malignant catarrhal fever, with an emphasis on ovine herpesvirus 2. Vet Pathol 51(2):437-452

2. Headley SA, Oliveira TES, Cunha CW (2020) A review of the epidemiological, clinical, and pathological aspects of sheep-associated malignant catarrhal fever with emphasis on Brazil. Braz J Microbiol 51:1405-1432

3. Li H, Cunha CW, Taus NS, Knowles DP (2014) Malignant catarrhal fever: inching toward understanding. Annul Rev Anim Biosci 2:209-233

4. Li H, Keller J, Knowles DP, Crawford TB (2001) Recognition of another member of the malignant catarrhal fever virus group: an endemic gammaherpesvirus in domestic goats. J Gen Virol 82(Pt 1):227-232

5. Li H, Gailbreath K, Flach EJ, Taus NS, Cooley J, Keller J, Russell GC, Knowles DP, Haig DM, Oaks JL, Traul DL, Crawford TB (2005) A novel subgroup of rhadinoviruses in ruminants. J Gen Virol 86(Pt 11):3021-3026

6. Li H, Gailbreath K, Bender LC, West K, Keller J, Crawford TB (2003) Evidence of three new members of malignant catarrhal fever virus group in muskox (Ovibos moschatus), Nubian ibex (Capra nubiana), and gemsbok (Oryx gazella). J Wildl Dis 39(4):875-880

7. ICTV. (2020). "Virus taxonomy: 2020 release - Order Herpesvirales." Retrieved 12 May, 2021), from .

8. Russell GC, Stewart JP, Haig DM (2009) Malignant catarrhal fever: a review. Vet J 179(3):324-335

9. Constable P, Hinchcliff KW, Done S, Gruenberg W (2017). Malignant catarrhal fever. (ed). Veterinary medicine: a textbook of the diseases of cattle, horses, sheep, pigs, and goats. St. Louis, Missouri, Elsevier: 2076-2080.

10. Uzal FA, Plattner BL, Hostetter JM (2016). Alimentary system. In: Maxie, M.G. (ed). Jubb, Kennedy, and Palmer's pathology of domestic animals. St. Louis, Missouri, Elsevier.Vol. 2: 1-257.

11. O'Toole D, Li H, Miller D, Williams WR, Crawford TB (1997) Chronic and recovered cases of sheep-associated malignant catarrhal fever in cattle. Vet Rec 140(20):519-524

12. O'Toole D, Li H, Roberts S, Rovnak J, DeMartini J, Cavender J, Williams B, Crawford T (1995) Chronic generalized obliterative arteriopathy in cattle: a sequel to sheep-associated malignant catarrhal fever. J Vet Diagn Invest 7(1):108-121

13. Martins MSN, Castro AMMG, Lima MS, Pinto VSC, Silva TG, Fava CD, Depes CR, Okuda LH, Pituco EM (2017) Malignant catarrhal fever in Brazilian cattle presenting with neurological syndrome. Braz J Microbiol 48:366-372

14. Mitchell ESE, Scholes SFE (2009) Unusual presentation of malignant catarrhal fever involving neurological disease in young calves. Vet Rec 164(8):240-242

15. Headley SA, Oliveira TES, Li H, Lisbôa JAN, Queiroz GR, Fritzen JTT, Flores EF, Alfieri AA, Cunha CW (2020) Immunohistochemical detection of intralesional antigens of Ovine 
Gamaherpesvirus-2 in cattle with Sheep-Associated Malignant Catarrhal Fever. J Comp Path 174:86-98

16. Li H, McGuire TC, Muller-Doblies UU, Crawford TB (2001) A simpler, more sensitive competitive inhibition enzyme-linked immunosorbent assay for detection of antibody to malignant catarrhal fever viruses. J Vet Diagn Invest 13(4):361-364

17. O'Toole D, Li H, Sourk C, Montgomery DL, Crawford TB (2002) Malignant catarrhal fever in a bison (Bison bison) feedlot, 19932000. J Vet Diagn Invest 14(3):183-193

18. Sausker EA, Dyer NW (2002) Polymerase chain reaction and DNA sequencing for detection of Ovine Herpesvirus 2 in American Bison (Bison bison). J Vet Diagn Invest 14(1):40-46

19. Oliveira TES, Scuisato GS, Pelaquim IF, Cunha CW, Cunha LS, Flores EF, Pretto-Giordano LG, Lisbôa JAN, Alfieri AA, Saut JPE, Cunha PHJ, Headley SA (2021) The participation of a virus within the malignant catarrhal fever virus group and Mycoplasma bovis in the development of single and mixed infections in beef and dairy cattle with bovine respiratory disease. Front Vet Sci. https://doi.org/10.3389/fvets.2021.691448

20. Headley SA, Müller MC, de Oliveira TES, Barros Gil Duarte CA, Valente Pereira PF, Vieira MV, Cunha CW, Flores EF, Lisbôa JAN, Pretto-Giordano LG. (2020) Diphtheric aspergillosis tracheitis with gastrointestinal dissemination secondary to viral infections in a dairy calf. Microb Pathog. 149:104497.

21. Xavier AAC (2021) Ocorrência do vírus da febre catarral maligna em bovinos do estado do Paraná, Sul do Brasil: um estudo imunohistoquímico retrospectivo. MSc Master's of Science Dissertation, Universidade Estadual de Londrina

22. Oliveira TES, Pelaquim IF, Flores EF, Massi RP, Valdiviezo MJJ, Pretto-Giordano LG, Alfieri AA, Saut JPE, Headley SA (2020) Mycoplasma bovis and viral agents associated with the development of bovine respiratory disease in adult dairy cows. Transbound Emerg Dis 67:82-93

23. Headley SA, Oliveira VH, Figueira GF, Bronkhorst DE, Alfieri AF, Okano W, Alfieri AA (2013) Histophilus somni-induced infections in cattle from southern Brazil. Trop Anim Health Prod 45(7):1579-1588

24. Alfieri AA, Parazzi ME, Takiuchi E, Médici KC, Alfieri AF (2006) Frequency of group A rotavirus in diarrhoeic calves in Brazilian cattle herds, 1998-2002. Trop Anim Health Prod 38(7-8):521-526

25. Boom R, Sol CJ, Salimans MM, Jansen CL, Wertheim-van Dillen PM, van der Noordaa J (1990) Rapid and simple method for purification of nucleic acids. J Clin Microbiol 28(3):495-503

26. Baxter SI, Pow I, Bridgen A, Reid HW (1993) PCR detection of the sheep-associated agent of malignant catarrhal fever. Arch Virol 132(1-2):145-159

27. Vilcek S, Herring AJ, Herring JA, Nettleton PF, Lowings JP, Paton DJ (1994) Pestiviruses isolated from pigs, cattle and sheep can be allocated into at least three genogroups using polymerase chain reaction and restriction endonuclease analysis. Arch Virol 136(3-4):309-323

28. Vilcek S, Elvander M, Ballagi-Pordany A, Belak S (1994) Development of nested PCR assays for detection of bovine respiratory syncytial virus in clinical samples. J Clin Microbiol 32(9):2225-2231

29. Claus MP, Alfieri AF, Folgueras-Flatschart AV, Wosiacki SR, Médici KC, Alfieri AA (2005) Rapid detection and differentiation of bovine herpesvirus 1 and 5 glycoprotein $\mathrm{C}$ gene in clinical specimens by multiplex-PCR. J Virol Methods 128(1-2):183-188

30. Takiuchi E, Stipp DT, Alfieri AF, Alfieri AA (2006) Improved detection of bovine coronavirus $\mathrm{N}$ gene in faeces of calves infected naturally by a semi-nested PCR assay and an internal control. J Virol Methods 131(2):148-154
31. Zhu YM, Shi HF, Gao YR, Xin JQ, Liu NH, Xiang WH, Ren XG, Feng JK, Zhao LP, Xue F (2011) Isolation and genetic characterization of bovine parainfluenza virus type 3 from cattle in China. Vet Microbiol 149(3-4):446-451

32. Angen O, Thomsen J, Larsen LE, Larsen J, Kokotovic B, Heegaard PM, Enemark JM (2009) Respiratory disease in calves: microbiological investigations on trans-tracheally aspirated bronchoalveolar fluid and acute phase protein response. Vet Microbiol 137(1-2):165-171

33. Townsend KM, Frost AJ, Lee CW, Papadimitriou JM, Dawkins HJ (1998) Development of PCR assays for species- and type-specific identification of Pasteurella multocida isolates. J Clin Microbiol 36(4):1096-1100

34. Angen O, Ahrens P, Tegtmeier C (1998) Development of a PCR test for identification of Haemophilus somnus in pure and mixed cultures. Vet Microbiol 63(1):39-48

35. Voltarelli DC, de Alcântara BK, Lunardi M, Alfieri AF, de Arruda LR, Alfieri AA (2018) A nested-PCR strategy for molecular diagnosis of mollicutes in uncultured biological samples from cows with vulvovaginitis. Anim Reprod Sci 188:137-143

36. Headley SA, Pimentel LA, Oliveira VH, Toma HS, Alfieri AF, Carvalho AM, dos Santos MD, Alfieri AA (2015) Transplacental transmission of Ovine Herpesvirus 2 in cattle with sheep-associated malignant catarrhal fever. J Comp Path 153(4):206-211

37. Headley SA, Okano W, Balbo LC, Marcasso RA, Oliveira TES, Alfieri AF, Negri Filho LC, Michelazzo MMZ, Rodrigues SMC, Baptista AL, Saut JPE, Alfieri AA (2018) Molecular survey of infectious agents associated with bovine respiratory disease in a beef cattle feedlot in southern Brazil. J Vet Diagn Invest 30(2):249-251

38. Headley SA, Alfieri AF, Oliveira VHS, Beuttemmüller EA, Alfieri AA (2014) Histophilus somni is a potential threat to beef cattle feedlots from Brazil. Vet Rec 175(10): 249

39. Hall TA (1999) BioEdit: a user-friendly biological sequence alignment editor and analysis program for Windows 95/98/NT. Nucleic Acids Symp 41:95-98

40. Kumar S, Stecher G, Li M, Knyaz C, Tamura K (2018) MEGA 7: molecular evolutionary genetics analysis across computing platforms. Mol Biol Evol 35:1547-1549

41. Jukes TH, Cantor CR (1969) Evolution of protein molecules. In: Munro H (ed) Mammalian protein metabolism. Academic Press, New York, pp 21-132

42. Nei M, Kumer S (2020) Molecular evolution and phylogenetics. Oxford University Press, New York

43. Schultheiss PC, Collins JK, Austgen LE, DeMartini JC (1998) Malignant catarrhal fever in bison, acute and chronic cases. J Vet Diagn Invest 10(3):255-262

44. Headley SA, Agnol AMD, Navolar FMN, Frucchi APS, Matos AMRN, Pereira PFV, Xavier AAC, Santos VH, Silva LE, Depes VCA, Alfieri AF, Cunha CW, Alfieri AA. (2021) Ovine gammaherpesvirus-2 infection associated with chronic interstitial pneumonia in a sheep. Microb Pathog. 161

45. Powers JG, VanMetre DC, Collins JK, Dinsmore RP, Carman J, Patterson G, Brahmbhatt D, Callan RJ (2005) Evaluation of ovine herpesvirus type 2 infections, as detected by competitive inhibition ELISA and polymerase chain reaction assay, in dairy cattle without clinical signs of malignant catarrhal fever. J Am Vet Med Assoc 227(4):606-611

46. Luvizotto M, Ferrari H, Cardoso T (2010) Malignant catarrhal fever-like lesions associated with ovine herpesvirus-2 infection in young calves (Bos indicus): a case report. J Venom Anim Toxins incl Trop Dis 16:178-185

47. Mebus CA, Stair EL, Rhodes MB, Twiehaus MJ (1973) Pathology of neonatal calf diarrhea induced by a coronavirus-like agent. Vet Pathol 10(1):45-64 
48. Vlasova AN, Saif LJ. (2021) Bovine coronavirus and the associated diseases. Front Vet Sci. 8(293): https://doi.org/10.3389/fvets. 2021.643220.

49. Zappulli V, Ferro S, Bonsembiante F, Brocca G, Calore A, Cavicchioli L, Centelleghe C, Corazzola G, De Vreese S, Gelain ME, Mazzariol S, Moccia V, Rensi N, Sammarco A, Torrigiani F, Verin R, Castagnaro M (2020) Pathology of coronavirus infections: a review of lesions in animals in the One-Health Perspective. Animals 10(12):2377

50. Isernhagen AJ, Cosenza M, da Costa MC, Médici KC, Balarin MRS, Bracarense APFRL, Alfieri AA, Lisbôa JAN (2011) Asymptomatic encephalitis in calves experimentally infected with bovine herpesvirus-5. Can Vet J 52(12):1312-1318

51. Beuttemmuller EA, Alfieri AF, Headley SA, Alfieri AA. (2017) Brazilian strain of bovine respiratory coronavirus is derived from dual enteric and respiratory tropism. Genet Mol Res. 16(2):https:// doi.org/10.4238/gmr16029580.

52. Boileau MJ, Kapil S (2010) Bovine coronavirus associated syndromes. Vet Clin North Am Food Anim Pract 26(1):123-146

53. Saif LJ (2010) Bovine respiratory coronavirus. Vet Clin North Am Food Anim Pract 26(2):349-364

54. Ellis $\mathbf{J}$ (2019) What is the evidence that bovine coronavirus is a biologically significant respiratory pathogen in cattle? Can Vet J 60(2):147-152

55. Cho Y-I, Yoon K-J (2014) An overview of calf diarrhea - infectious etiology, diagnosis, and intervention. J Vet Sci 15(1):1-17

56. Headley SA, Alfieri AA, Fritzen JTT, Queiroz GR, Lisbôa JAN, Netto DP, Okano W, Flaiban KKMC, Alfieri AF (2014) Concomitant bovine viral diarrhea, mycotoxicosis, and seneciosis in beef cattle from northern Paraná. Brazil Semin: Cenc-Agrar 35(5):2563-2576

57. Cunha CW, Gailbreath KL, O'Toole D, Knowles DP, Schneider DA, White SN, Taus NS, Davies CJ, Davis WC, Li H (2012)
Ovine herpesvirus 2 infection in American bison: virus and host dynamics in the development of sheep-associated malignant catarrhal fever. Vet Microbiol 159(3):307-319

58. Hierweger MM, Boujon CL, Kauer RV, Meylan M, Seuberlich T, Oevermann A (2021) Cerebral Ovine Herpesvirus 2 infection of cattle is associated with a variable neuropathological phenotype. Vet Pathol 58(2):384-395

59. Pesavento PA, Cunha CW, Li H, Jackson K, O'Toole D (2019) In situ hybridization for localization of Ovine Herpesvirus 2, the agent of sheep-associated malignant catarrhal fever, in formalinfixed tissues. Vet Pathol 56:78-86

60. Headley SA, Lisbôa JAN, Fritzen JTT, Queiroz GR, Alfieri AF, Oliveira RAM, Bracarense APFRL, Flaiban KKMC, Alfieri AA. (2013) Ovine herpesvirus type 2-induced malignant catarrhal fever in a heifer. Semin: Cenc-Agrar. 34(6,S2):3903-3908

61. Rech RR, Schild AL, Driemeier D, Garmatz SL, Oliveira FN, Riet-Correa F, Barros CSL (2005) Malignant catarrhal fever in cattle in Rio Grande do Sul, Brazil: epidemiology, clinical signs and pathology. Pesq Vet Bras 25:97-105

62. Palmer MV, Thacker TC, Madison RJ, Koster LG, Swenson SL, Li $\mathrm{H}$ (2013) Active and latent ovine herpesvirus-2 (OvHV-2) infection in a herd of captive white-tailed deer (Odocoileus virginianus). J Comp Path 149(2):162-166

63. Epp T, Waldner C, Woodbury M (2016) An observational study of mortality on bison farms in Saskatchewan with special emphasis on malignant catarrhal fever. Can Vet J 57(1):37-45

64. Li H, Karney G, O’Toole D, Crawford TB (2008) Long distance spread of malignant catarrhal fever virus from feedlot lambs to ranch bison. Can Vet J 49(2):183-185

Publisher's note Springer Nature remains neutral with regard to jurisdictional claims in published maps and institutional affiliations.

\section{Authors and Affiliations}

\section{Selwyn Arlington Headley ${ }^{1,2,3}$ (1) - Gisele Augusta Amorim de Lemos ${ }^{1} \cdot$ Alais Maria Dall Agnol $^{3,4}$. Ana Aparecida Correa Xavier ${ }^{1}$. Victória Coronado Antunes Depes ${ }^{5} \cdot$ Carolina Yuka Yasumitsu $^{4}$. Thalita Ernani Silva Oliveira ${ }^{1}$ - Luara Evangelista Silva ${ }^{1} \cdot$ Tatiane Cargnin Faccin $^{1}$ - Amauri Alcindo Alfieri ${ }^{3,4,6}$. Júlio Augusto Naylor Lisboa ${ }^{3,5}$}

1 Laboratory of Animal Pathology, Department of Veterinary Preventive Medicine, Universidade Estadual de Londrina, Rodovia Celso Garcia Cid, PR 445 Km 380, Campus Universitário, PO Box 10.011, Paraná 86057-970, Brazil

2 Multi-User Animal Health Laboratory, Tissue Processing Unit, Department of Veterinary Preventive Medicine, Universidade Estadual de Londrina, Paraná, Brazil

3 National Institute of Science and Technology of Dairy Production Chain (INCT-Leite), Universidade Estadual de Londrina, Paraná, Brazil
4 Laboratory of Animal Virology, Department of Preventive Veterinary Medicine, Universidade Estadual de Londrina, Paraná, Brazil

5 Large Animal Internal Medicine, Department of Veterinary Clinics, Universidade Estadual de Londrina, Paraná, Brazil

6 Multi-User Animal Health Laboratory, Molecular Biology Unit, Department of Veterinary Preventive Medicine, Universidade Estadual de Londrina, Paraná, Brazil 